\title{
Physiological Behave of Acai Seedlings (Euterpe precatoria MART.) under Increasing Levels of Irradiance
}

\author{
C. F. Coelho ${ }^{1}$, Ires Miranda ${ }^{1}, Z^{2}$ ilvanda Melo ${ }^{1} \&$ Edelcílio Barbosa ${ }^{1}$ \\ ${ }^{1}$ Research Group Amazon palm trees, Departament of Botany, Amazon Research National Institute, Manaus, \\ Brazil
}

Correspondence: C. F. Coelho, Labpalm, Amazon Research National Institute, Manaus, Brazil. Tel: 55-92-3643-3108. E-mail: carlacoelhofigueiredo@gmail.com

Received: December 23, 2014 Accepted: January 26, 2015 Online Published: February 15, 2015

doi:10.5539/jas.v7n3p236 URL: http://dx.doi.org/10.5539/jas.v7n3p236

\begin{abstract}
The palm tree Euterpe precatoria Mart. is distributed all over the amazon region. The extractive exploitation mainly in coastal communities, where its use is essential in food, presents insufficient to attend a business model in isolated communities. As a result, management plans are required for the survival of this species. One of the primary limiting factors for seedling growth is light, with a view to its direct link with the photosynthetic efficiency. Among the main factors linked to the photosynthetic efficiency of plants and therefore to their establishment and development in different environments, is the concentration of chloroplastidic pigments (chlorophyll a, b and carotenoids). Based on the assumptions pointed the aim of this study was based on obtaining of knowledge and the potential of applicability on the production system of plant bags of this species from possible physiological characteristics of adaptability developed by E. precatoria Mart seedlings submitted to different conditions irradiance availability. Particularly, on the regulation of the concentrations of chloroplastidic pigments. Among the evaluations carried out in this work it can be said that Euterpe precatoria under different light intensities, proved probably acclimatized. This behavior suggests that the species tolerates environments with different levels of irradiance, about the increase of biomass and carotenoid content and chlorophyll a, there is no significant differences and showed higher levels for chlorophyll $b$ in shaded environments (Engel \& Poggiani, 1991; Kahn \& De Granville, 1992).
\end{abstract}

Keywords: Amazon, monocot, palm tree, photosynthesis, shading, tropical

\section{Introduction}

The palm tree Euterpe precatoria Mart is distributed throughout the Amazon region (Kahn \& De Granville, 1992; Miranda, Rabelo, Bueno, Barbosa, \& Ribeiro, 2001; Miranda, Barbosa, Rabelo, \& Santiago, 2008). The mechanism of propagation of the species is through seeds, due to the fact that they do not present tillers as $E$. oleracea. However germination is generally characterized by difficulties which range from the morphological characteristics of seeds to the physiological peculiarities of the germination process, hindering the production and subsequent seedling establishment. One of the limiting factors to the primary seedling growth is light, with a view to its direct link with the photosynthetic efficiency. In studies conducted to evaluate the responses of growth, photosynthesis, distribution of biomass and stomatal conductance due to different conditions of irradiance in woody seedlings of a tropical deciduous forest, the species that showed a higher relative growth also showed higher plasticity reaching the highest rates photosynthetic and stomatal conductance in response to light changes, followed by species with intermediate growth; the slow-growing species were less plastic (Huante \& Kicon, 1997).

Much of the success of adaptation of plants is due to this efficient photosynthetic mechanism, important biological process in which culminates in the conversion of light energy into chemical energy resulting in a high production of plant biomass, favoring the storage conditions of substances of primary metabolism, including carbohydrates, in which they are responsible for $60 \%$ or more of plant dry matter. This process has as the main photoreceptor pigment the chlorophyll a $\left(\mathrm{C}_{55} \mathrm{H}_{72} \mathrm{~N}_{4} \mathrm{O}_{5} \mathrm{Mg}\right)$. However chlorophyll b $\left(\mathrm{C}_{55} \mathrm{H}_{70} \mathrm{~N}_{4} \mathrm{O}_{6} \mathrm{Mg}\right)$ and the carotenoids have the capacity to expand the range of light radiation of the solar spectrum that can be used on photosynthesis besides being associated with photoprotective mechanisms for thermal dissipation of excess absorbed energy (Engel \& Poggiani, 1991; Gonçalves, Fernandes, Oliveira, Rodrigues, \& Marenco, 2002). These 
pigments are found in the leaf mesophyll and act as an antenna complex, collecting light and transferring to the reaction centers, where there is the oxidation and reduction reactions promoting long-term energy storage (Taiz \& Zeiger, 2004). Therefore, among the main factors related to the photosynthetic efficiency of plants and therefore to their establishment and development in different environments, is the concentration of chloroplastid pigments. However the efficiency of the photosynthetic process may vary according to the availability of other exogenous factors (light, $\mathrm{CO}_{2}, \mathrm{H}_{2} \mathrm{O}$, nutrients, temperature), and/or endogenous (concentration of carbohydrates and nutrients) (Larcher, 2000). About the light it is known that some plants have sufficient plasticity of development to adaptate to an amplitude of light regime, growing as a light plant in sunny areas and as a shade plant in shaded habitats (Huante \& Kicon, 1997). Therefore this study aims to obtain the knowledge with potential of applicability in the system of production of seedlings of this species from the possible physiological characteristics of adaptability developed by seedlings of E. precatoria submitted to different conditions of availability of irradiance particularly, on the regulation of concentrations of chloroplastidic pigments.

\section{Materials and Methods}

\subsection{Study Area}

The study was conducted at the Laboratory of Palm Studies - LabPalm, Biodiversity Coordination (CBIO) of the National Institute for Amazonian Research (MCTI - INPA), located in Manaus, AM, with South Latitude $3^{\circ} 5^{\prime} 44.27^{\prime \prime}$, West Longitude 59 $59^{\prime} 13.93^{\prime \prime}$, with an average altitude of $86 \mathrm{~m}$.

\subsection{Experiment with Different Levels of Irradiance}

Seedlings of Euterpe precatoria were selected in the nursery of the Laboratory of studies in Palm INPA (LABPALM), for uniformity of size and plant health. The transplanting in black plastic bags was made, with a capacity of $2 \mathrm{~kg}$ of mixture (composted material, vermiculite) and subjected to four treatments with increasing densities of light obtained with polyolefin screen (shading). Each treatment consisted of seven plants, consisting of:

$$
\begin{aligned}
& \mathrm{T} 1=30 \%\left(200 \text { a } 400 \mu \mathrm{mol} \text { photons } \mathrm{m}^{-2} \mathrm{~s}^{-1}\right)^{*} ; \\
& \mathrm{T} 2=50 \%\left(500 \text { a } 700 \mu \mathrm{mol} \text { photons } \mathrm{m}^{-2} \mathrm{~s}^{-1}\right)^{*} ; \\
& \mathrm{T} 3=70 \% \text { of irradiance }\left(800 \text { a } 1000 \mu \mathrm{mol} \text { photons } \mathrm{m}^{-2} \mathrm{~s}^{-1}\right)^{*} ; \\
& \mathrm{T} 4=\text { full sun }\left(1300 \text { a } 1800 \mu \mathrm{mol} \text { photons } \mathrm{m}^{-2} \mathrm{~s}^{-1}\right)^{*} ; \\
& * \text { Bands of light may vary depending on the season of installation of experiment. }
\end{aligned}
$$

Seven plants were subjected to each treatment, samples of four plants were taken alternately to compose four repetitions in order to not harm the plants whereas they were removed two leaflets every 15 days. The assay was monitored over a period of 210 days. During the execution of the assay it was analyzed the contents of chloroplastidic pigments (chlorophylls a and $\mathrm{b}$ and carotenoids) every 15 days and the biomass content ( $\mathrm{g}$ ) at the beginning and end of the experiment.

\subsection{Determination of Contents of Chloroplastidic Pigments}

The determination of contents of chloroplastidic pigments was performed in fully expanded and healthy leaves located in the middle third of the seedlings. In each treatment were collected two leaflets per seedling to compose, in four individuals for treatment, always obeying the interval from 16 to 18 hours. The collected material was wrapped in aluminum foil and taken immediately to the laboratory where it was processed in the dark. The extraction of the pigments was done according to the method of (Lichtenthaler \& Wellburn, 1983) to each individual, $0.1 \mathrm{~g}$ of fresh vegetable material from the leaflets was homogenized in $10 \mathrm{ml}$ of acetone $(100 \%$ $\mathrm{v} / \mathrm{v})$ and subsequently in $10 \mathrm{ml}$ of an acetone solution $(80 \% \mathrm{v} / \mathrm{v})$ containing $\mathrm{MgCO}_{3}(0.5 \% \mathrm{w} / \mathrm{v})$. Then the extract was filtered through qualitative filter paper No. 1. From this filtered extract the contents of pigments were determined by absorbance, obtained by spectrophotometer, the following wavelengths $(\lambda): 663 \mathrm{~nm}$ and $645 \mathrm{~nm}$ and $480 \mathrm{~nm}$ for chlorophyll a (Cla), chlorophyll b $(\mathrm{Clb})$ and carotenoids (Car), respectively. The calculation of concentrations of chloroplastidic concentrations was based on fresh leaf weight $\left(\mu \mathrm{mol} \mathrm{g}{ }^{-1}\right)$ according to Hendry and Price (1993), where:

$$
\text { Chlorophyl a }\left(\mu \mathrm{mol} \mathrm{g}^{-1}\right)=\frac{(12.7 \times A 663-2.69 \times A 645) \times 1.119 \times V}{1000 \times \text { unit of mass }(g)}
$$




$$
\begin{aligned}
& \text { Chlorophyl b }\left(\mu \mathrm{mol} \mathrm{g}^{-1}\right)=\frac{(22.9 \times A 645-4.68 \times A 663) \times 1.102 \times V}{1000 \times \text { unit of mass }(\mathrm{g})} \\
& \text { Carotenoids }\left(\mu \mathrm{mol}^{-1}\right)=\frac{(A 480+0.114 \times A 663-0.638 \times A 645) \times V}{1000 \times \text { unit of mass }(\mathrm{g})}
\end{aligned}
$$

In these equations, $\mathrm{A}$ is the absorbance at the wavelength used and $\mathrm{V}$ is the final volume of the extract obtained $(\mathrm{ml})$.

\subsection{Statistical Analysis}

The results were submitted to analysis of variance and means were compared with each other by 5\% Tukey test, considering the normality we used the Kruskal Wallis test in two periods of analysis (Zar, 1974) using the Program ASSISTAT - Assistance Statistics (version 7.7 Beta) UFCG - Campina Grande-PB (Silva \& Azevedo, 2009).

\section{Results and Discussion}

In this study, no significant differences were observed $(p<0.05)$ between the four treatments in relation to biomass and concentration of chlorophyll a and carotenoids, 210 days after implantation. According to Uenojo et. al (2007), the levels of carotenoids in cells of leaves and fruits remain relatively constant until the beginning of senescence, which was found in this study (Tables 1, 2 and 3).

Table 1. Root biomass, stem and shoot of the palm tree Euterpe precatória Mart. cultivated under different irradiance levels at 210 days after implantation

\begin{tabular}{llll}
\hline & Root $(\mathbf{g})$ & Stem $(\mathbf{g})$ & Shoot $(\mathbf{g})$ \\
\hline T1 (30 \% of irradiance) & $9.18400 \mathrm{a}$ & $5.51600 \mathrm{a}$ & $9.44000 \mathrm{a}$ \\
T2 (50 \% of irradiance) & $8.96000 \mathrm{a}$ & $5.84000 \mathrm{a}$ & $8.80000 \mathrm{a}$ \\
T3 (70 \% of irradicance) & $8.64000 \mathrm{a}$ & $5.70000 \mathrm{a}$ & $8.50000 \mathrm{a}$ \\
T4 (Full sun) & $9.60000 \mathrm{a}$ & $5.55600 \mathrm{a}$ & $9.66000 \mathrm{a}$ \\
\hline
\end{tabular}

Note. Same letter within each treatment, show no statistical difference at 5\% probability by Tukey test. 
Table 2. Levels of carotenoids expressed per unit leaf area in 4 treatments on the acai palm tree leaves, Euterpe precatoria Mart., Arecaceae

\begin{tabular}{|c|c|c|c|c|c|}
\hline \multirow[b]{2}{*}{ Time (days) } & \multicolumn{5}{|c|}{ Irradiance } \\
\hline & $30 \%$ & $50 \%$ & $70 \%$ & Full sunlight & $\mathrm{F}$ \\
\hline $\mathbf{0}$ & 0,7367678 & 0,5453858 & 0,8018419 & 0,773263559 & $2,1759^{\mathrm{ns}}$ \\
\hline 15 & 1,1552058 & 0,8609924 & 1,1979174 & 1,155009301 & $1,4979^{\mathrm{ns}}$ \\
\hline 30 & 1,0281754 & 0,8785357 & 0,7787888 & 0,938595976 & $1,2408^{\mathrm{ns}}$ \\
\hline 45 & 1,2242213 & 1,1937578 & 1,0963208 & 1,147714414 & $0,1299^{\mathrm{ns}}$ \\
\hline 60 & 1,0920442 & 0,9702212 & 0,9555385 & 0,973293661 & $0,2443^{\mathrm{ns}}$ \\
\hline 75 & 1,347083 & 1,0301829 & 0,971845 & 1,060926748 & $1,0798^{\mathrm{ns}}$ \\
\hline 90 & 1,213751 & 1,0951361 & 1,3067634 & 1,233971457 & $0,5422^{\mathrm{ns}}$ \\
\hline 105 & 1,7341374 & 1,6085382 & 1,5461866 & 1,397051768 & $2,5655^{\mathrm{ns}}$ \\
\hline 120 & 1,3361059 & 1,3134722 & 1,4616431 & 1,196978125 & $0,5671^{\mathrm{ns}}$ \\
\hline 135 & 1,3353752 & 1,7256033 & 1,2887127 & 1,38075286 & $2,1814^{\mathrm{ns}}$ \\
\hline 150 & 1,3930786 & 1,1254664 & 1,4746093 & 1,292373122 & $1,8971^{\mathrm{ns}}$ \\
\hline 165 & 1,4964715 & 1,8855352 & 1,8831265 & 1,764750209 & $3,0986^{\mathrm{ns}}$ \\
\hline 180 & 1,8189348 & 1,6746794 & 1,8792692 & 1,593215777 & $0,7113^{\mathrm{ns}}$ \\
\hline 195 & 1,8273972 & 1,7847125 & 1,8294073 & 1,65023722 & $0,6346^{\mathrm{ns}}$ \\
\hline 210 & 1,5645809 & 1,5588311 & 1,5466482 & 1,298004294 & $3,0756^{\mathrm{ns}}$ \\
\hline
\end{tabular}

Note. $\mathrm{F}$ critical: $3.4904 ; \mathrm{CV}<30 ; \mathrm{ns}$ is no statistically significant difference $(p<0.05)$.

Table 3. Levels of chlorophyll $a$ expressed per unit leaf area in 4 treatments on the acai palm tree leaves, Euterpe precatoria Mart., Arecaceae

\begin{tabular}{|c|c|c|c|c|c|c|c|c|}
\hline & & & & & Irradiance & & & \\
\hline Time (days) & $30 \%$ & $50 \%$ & $70 \%$ & Full sunlight & $F$ & $\mathrm{H}$ & $\mathrm{H}$ critical & Test \\
\hline $\mathbf{0}$ & 1,468 & 1,164 & 1,504 & 1,549 & $2,167^{\mathrm{ns}}$ & & & Tukey \\
\hline 15 & 2,584 & 1,902 & 2,755 & 2,441 & $1,4883^{\mathrm{ns}}$ & & & Tukey \\
\hline 30 & 1,992 & 1,805 & 1,840 & 2,056 & $0,7254^{\mathrm{ns}}$ & & & Tukey \\
\hline 45 & 2,912 & 2,853 & 2,611 & 2,541 & $0,2584^{\mathrm{ns}}$ & & & Tukey \\
\hline 60 & 2,607 & 2,464 & 2,448 & 2,288 & $0,2034^{\mathrm{ns}}$ & & & Tukey \\
\hline 75 & 3,339 & 2,948 & 2,491 & 2,701 & $1,4517^{\mathrm{ns}}$ & & & Tukey \\
\hline 90 & 2,994 & 2,857 & 3,348 & 3,327 & $3,1508^{\mathrm{ns}}$ & & & Tukey \\
\hline 105 & 3,622 & 3,543 & 3,545 & 3,480 & $1,2402^{\mathrm{ns}}$ & & & Tukey \\
\hline 120 & 3,267 & 3,170 & 3,440 & 2,997 & $1,0789^{\mathrm{ns}}$ & & & Tukey \\
\hline 135 & 3,239 & 3,536 & 3,027 & 3,256 & $2,2585^{\text {ns }}$ & & & Tukey \\
\hline 150 & 3,217 & 3,037 & 3,229 & 3,234 & $0,8526^{\text {ns }}$ & & & Tukey \\
\hline 165 & 3,508 & 3,526 & 3,495 & 3,534 & $0,1951^{\mathrm{ns}}$ & & & Tukey \\
\hline 180 & 3,880 & 3,449 & 3,625 & 3,278 & & $7,3^{\mathrm{ns}}$ & 11,34 & Kruskal-Wallis \\
\hline 195 & 3,641 & 3,557 & 3,575 & 3,433 & $1,4827^{\mathrm{ns}}$ & & & Tukey \\
\hline 210 & 3,226 & 3,079 & 3,202 & 2,765 & & $6^{\mathrm{ns}}$ & 7,81 & Kruskal-Wallis \\
\hline
\end{tabular}

Note. F critical: 3.4904; CV <30; ns is no statistically significant difference by the Tukey test and Kruskal Wallis test $(p=\alpha<0.05)$. 
The different levels of irradiance caused no effect on root biomass increment, stem and leaves in the seedlings of the studied species, as seen in Table 1. A similar result was found by Countin and Conforto (2009) in a study conducted in the state of Para/Brazil with Euterpe oleracea Mart plant. in eight months of analysis, in which the light treatments $(50 \%$ and $84 \%)$ did not significantly alter the average dry matter of stem, root and leaves. However, in another experiment conducted by Nakazono et al. (2001), with plants of Euterpe edulis Mart., coming from the Atlantic Forest region subjected to the same conditions as those of the present study (period of 199 days), it was noted that plants in direct light condition had lower dry matter in relation to under shade. In this study, it is noteworthy that this is another species and in different biome (Amazon). However, with respect to chlorophyll, this study found similar results to those of the authors mentioned above. The content of chlorophyll $b$ (Table 4) were proportionally larger than those of chlorophyll $a$ (Table 3) when the incidence of light was lower.

Table 4. Levels of chlorophyll $b$ expressed per unit leaf area in 4 treatments on the acai palm tree leaves, Euterpe precatoria Mart., Arecaceae

\begin{tabular}{llllll}
\hline \multicolumn{5}{c}{ Irradiance } \\
\hline Time (days) & $30 \%$ & $50 \%$ & $70 \%$ & Full sunlight & $\mathrm{F}$ \\
$\mathbf{0}$ & 0,5351548 & 0,4157906 & 0,5489487 & 0,575420182 & $3,2192^{\mathrm{ns}}$ \\
$\mathbf{1 5}$ & 0,8762784 & 0,6667091 & 1,0225624 & 0,902548888 & $1,5804^{\mathrm{ns}}$ \\
$\mathbf{3 0}$ & 0,9320716 & 0,5809429 & 0,6488788 & 0,809969559 & $2,8703^{\mathrm{ns}}$ \\
$\mathbf{4 5}$ & 1,3392350 & 1,3374992 & 1,1690145 & 1,038465939 & $0,7241^{\mathrm{ns}}$ \\
$\mathbf{6 0}$ & 0,8360753 & 0,7350694 & 0,8528560 & 0,829474805 & $0,3510^{\mathrm{ns}}$ \\
$\mathbf{7 5}$ & 1,5140955 & 1,2434235 & 0,8492181 & 1,017280808 & $2,7448^{\mathrm{ns}}$ \\
$\mathbf{9 0}$ & 1,3576902 & 1,1399461 & 1,5411803 & 1,278822567 & $0,7939^{\mathrm{ns}}$ \\
$\mathbf{1 0 5}$ & 2,574961 & 2,5223332 & 2,2277182 & 1,634051655 & $3,2626^{\mathrm{ns}}$ \\
$\mathbf{1 2 0}$ & 1,5139694 & 1,7466673 & 1,7622477 & 0,826580755 & $1,0789^{\mathrm{ns}}$ \\
$\mathbf{1 3 5}$ & 1,3370298 & 2,1067839 & 1,2521884 & 1,373521236 & $2,2585^{\mathrm{ns}}$ \\
$\mathbf{1 5 0}$ & 1,4348558 & 1,0568706 & 1,3812086 & 1,226940512 & $1,2212^{\mathrm{ns}}$ \\
$\mathbf{1 6 5}$ & $1,905810 \mathrm{~b}$ & $3,0704953 \mathrm{a}$ & $2,7765976 \mathrm{ab}$ & $1,921612401 \mathrm{~b}$ & $4.9263^{*}$ \\
$\mathbf{1 8 0}$ & $2,6350736 \mathrm{a}$ & $1,883979 \mathrm{ab}$ & $2,3584489 \mathrm{ab}$ & $1,626498983 \mathrm{~b}$ & $4.2834^{*}$ \\
$\mathbf{1 9 5}$ & $2,2521464 \mathrm{ab}$ & $2,3989499 \mathrm{a}$ & $2,0567399 \mathrm{ab}$ & $1,393404615 \mathrm{~b}$ & $3.8726^{*}$ \\
$\mathbf{2 1 0}$ & $1,605067 \mathrm{ab}$ & $1,6649942 \mathrm{a}$ & $1,5125241 \mathrm{ab}$ & $1,043529803 \mathrm{~b}$ & $4.1681^{*}$ \\
\hline
\end{tabular}

Note. F critical: 3.4904; CV $<30$; ns is no statistically significant difference and different letters within each time, reveal statistical differences by the Tukey test $(p<0.05)$.

From the 165 days after implantation of the experiment, it was noted that all the plants in shading condition differed statistically from plants grown in full sun with higher chlorophyll $b$ content, this result was found to ultimately held at 210 days, after the implementation of the experiment. Carvalho et al. (2006) analyzing the initial growth of licuri palm (Syagrus coronata (MART.) BECC.) in different lighting conditions, also found a trend towards higher chlorophyll $b$ and total content $(\mathrm{a}+\mathrm{b})$ for plants exposed to $30 \%$ light than plants in full sunlight.

According to Engel and Poggiani (1991), the ambient light level that the plant grows is of fundamental importance, because the plant adaptation to this environment depends on the setting of their photosynthetic apparatus, so that the ambient light is used in the most efficient as possible. The chloroplast pigments are one of the factors related to the photosynthetic efficiency and thus the adaptability to diverse environments whereas they enable plants capture the greatest amount of photosynthetically active solar radiation.

The composition of chloroplasts is flexible and is particularly responsive to ambient light, that changes the relative abundance of many of the protein complexes, which components are regulated genetically, and the organization of the photosynthetic apparatus of shade leaves reflects its adaptation to collect light more 
efficiently. This is represented by the higher investment in chlorophyll $b$ (Hendry \& Price, 1993).

The shade leaves have higher concentrations of chlorophyll per gram than leaves exposed to direct sunlight (Engel \& Poggiani, 1991). The ratio of chlorophyll $a$ and $b$ tends to decrease with the decrease of light due to the higher relative proportion of chlorophyll $b$ in shady environments (Givinish, 1988; Boardman, 1977). This increased accumulation of chlorophyll in more shaded levels may be due to a compensatory effect of species to the lower amount of available radiation (Boardman, 1977).

\section{Conclusion}

Through the evaluations carried out in this work can be inferred that the palm E. precatoria tolerate environments with different levels of irradiance, as there is a trend to higher relative proportion of chlorophyll $b$, which may be due to a compensatory effect of species to less amount of available radiation. The time required time to the physiological response of increased production of chlorophyll $b$ by shaded plants was 165 days. This effect may be the result of the adequacy of the photosynthetic mechanism that occurs so that the radiation can be filtered better in the process of acclimatization E. seedlings precatoria shaded environment. This behavior is a favorable feature for the production of sustainable seedlings purpose of use in the production chain of acai.

\section{References}

Boardman, N. K. (1977). Comparative photosynthesis of sun and shade plants. Annual Review of Plant Physiology, 28, 355-377. Retrieved from http://www.annualreviews.org/doi/pdf/10.1146/annurev.pp.28.060177.002035

Carvalho, N. O. S., Pelacani, C. R., Rodrigues, M. O. S., \& Crepaldi, I. C. (2006). Initial growth of licuri plants (Syagrus coronata (Mart.) Becc.) under different light intensity. Revista Árvore, 30(3), 351-357. http://dx.doi.org/10.1590/S0100-67622006000300005

Conforto, E. C., \& Contin, D. R. (2009). Nursery development of non-flooded açai palm (Euterpe Oleraceae, Mart, Pará cultivar) Under attenuation of solar radiation. Bragantia, 68(4), 979-983. http://dx.doi.org/10.1590/S0006-87052009000400018

Engel, V. L., \& Poggiani, F. (1991). Study of chlorophyll in the leaves and their appearance in light absorption as a function of shading in forestry species seedlings. Revista Brasileira de Fisiologia Vegetal, 3(1), 39-45. Retrieved from http://www.cnpdia.embrapa.br/rbfv/pdfs/v3n1p39.pdf

Givinish, T. J. (1988). Adaptation to sun and shade: a whole-plant perspective. Australian Journal of Plant Physiology, 15, 63-92. http://dx.doi.org/10.1071/PP9880063

Gonçalves, F. de C., Fernandes, A. V., Oliveira, A. F., Rodrigues, L. F., \& Marenco, R. (2002). Primary metabolism components of seeds from Brazilian Amazon tree species. Braz. J. Plant Physiology, 14(2), 139-142. http://dx.doi.org/10.1590/S1677-04202002000200009

Hendry, G. A. F., \& Price, A. H. (1993). Stress indicators: Chlorophylls and carotenoids. In G. A. F. Hendry \& J. P. Grime (Eds.), Methods in Comparative Plant Ecology (pp. 148-152). Chapman e Hall, London.

Huante, P., \& Kicon, E. (1997). Responses to light changes in tropical deciduous woody seedlings with contrasting growth rates. Oecologia, 113(1), 53-66. http://dx.doi.org/10.1007/s004420050353

Kahn, F., \& De Granville, J. (1992). Palms in forest ecosystems of Amazonia (p. 226). U.S.A., Springer-Verlag Berlin Heidelberg. http://dx.doi.org/10.1007/978-3-642-76852-1

Lichtenthaler, H. K., \& Wellburn, A. R. (1983). Determination of total carotenoids and chlorophyll $a$ and $b$ of leaf extracts in different solvents. Biochemical Societ Transactions, 591-603. Retrieved from http://www-06.all-portland.net/bst/011/0591/0110591.pdf

Larcher, W. (2000). Plant physiological ecology (p. 531). Editora Rima, São Carlos.

Miranda, I. P. A., Rabelo, A., Bueno, C. R., Barbosa, E. M., \& Ribeiro, M. N. S. (2001). Amazon palm fruit (p. 120). MCT/INPA. Manaus.

Miranda, I. P. A., Barbosa, E. M., Rabelo, A., \& Santiago, F. F. (2008). Palm tres from riparian communities as a sustainable resource in the Brasilian Amazon.

Nakazono, E. M., Costa, M. C. D. A., Futatsugi, K., \& Paulilo, M. T. S. (2001). Initial growth of Euterpe edulis Mart. in different light regimes. Revista Brasil. Bot., São Paulo, 24(2), 173-179. http://dx.doi.org/10.1590/S0100-84042001000200007

Silva, F. A. S., \& Azevedo, C. A. V. (2009). Principal Components Analysis in the Software Assistat-Statistical Attendance. In World Congress on Computers in Agriculture, 7, Reno-NV-USA: American Society of 
Agricultural and Biological Engineers.

Taiz, L., \& Zeiger, E. (2004). Plant physiology (3 ed., pp. 139-171). Artmed. Porto Alegre.

Unejo, M., Junior, M. R. M., \& Pastore, G. M. (2007). Carotenoids: properties, applications and biotransformation in flavor compounds. Quimica Nova, 30(3), 616-622. http://dx.doi.org/10.1590/S0100-40422007000300022

Zar, J. H. (1974). Bioestatistical analysis. Preice-Hall International, Inc. London.

\section{Copyrights}

Copyright for this article is retained by the author(s), with first publication rights granted to the journal.

This is an open-access article distributed under the terms and conditions of the Creative Commons Attribution license (http://creativecommons.org/licenses/by/3.0/). 